\title{
ОСНОВНІ МЕТОДИКИ МЕТОДОЛОГІї
}

\author{
Бабайлов В.К., канд. экон. наук, доцент \\ Левченко Я.С., доктор философии в отрасли «Социальные и \\ поведенческие науки", доцент \\ Харьковский национальный автомобильно-дорожный университет
}

Постановка проблеми. Сучасна практика дослідження та виробництва призводить до висновку, що будь-яка конкретна діяльність має свої, властиві тільки їй мету $i$ засоби ії досягнення. Так, мета економіки - організація вартості; мета інженерії - організація технік; мета адміністрації - організація персоналу; мета маркетингу - організація обміну. Можна навести й інші приклади цілей. Відомо, що мета визначає засоби, а кошти визначають результат. Результат - це реалізована за допомогою засобів мета.

Тому необхідно підкреслити, що саме організація, вибір засобів (методик і технік) визначає результат будь-якої діяльності; але в будь-якому дослідженні (в тому числі і в педагогіці вищої освіти) саме методики є важливішими за техніку - методики визначають і техніку. I серед усіх методик будь-якого конкретного виду діяльності $є$ основні методики, властиві тільки даній діяльності! Так, в економіці використовується, перш за все, економічний аналіз і синтез, економіко-математичне моделювання та інші. В інженерії - методики інженерного (технічного) контролю. В адміністрації - методики мотивації. Організовуються основні методики і в інших сферах діяльності. Однак до сих пір не проведена чітка класифікація основних методик за критерієм приналежності кожної з них конкретній сфері діяльності (економіці, інженерії, адміністрації, маркетингу, підприємництва, філософії, методології та іншим). Невирішеність даної проблеми ускладнює вибір основних методик для проведення конкретного дослідження.

Аналіз сучасних досліджень і публікацій показав, що існують різні та потрібні в практиці класифікації методик. Так, широке поширення та практичне застосування отримала класифікація, поділ методик на методики фундаментальних, експериментальних і прикладних досліджень [1-4]. Але це класифікація методик не за критерієм сфери їх застосування: такі методики застосовуються в усіх сферах діяльності. Така класифікація не відповідає на питання, які з цих методик є основними і в якому конкретному виді діяльності.

Це невирішені складові проблеми. I це питання поділу, класифікації основних методик за критерієм приналежності їх до певної сфери діяльності (економіці, методології та іншим) до сих пір не вирішене. Звичайно, постійна практика досліджень показує, що приблизний перелік основних методик економіки або інженерії, або адміністрації, або маркетингу, або підприємництва, або філософії і деяких інших сфер діяльності частково сформувався. Однак спеціальної роботи по точному виділенню класу таких методик і їх інтерпретації досі не проведено. I є сфера діяльності, роль якої в 
даний час (і особливо в майбутню епоху) буде тільки зростати; це сфера методології, яка включає і методологію педагогіки вищої освіти [2]. Тому проблема визначення, формування, організації класу основних методик самої методології є особливо актуальною.

Формулювання мети і задач статті. Метою дослідження стала організація, визначення класу основних методик власне методології. Це $є$ i предметом дослідження. Звідси випливає, що в нього не входять основні методики всіх інших сфер діяльності - це проблема окремого дослідження. Не включаються в предмет дослідження і загальні методики: огляд літературних джерел; методика 2С70 і методика ВЕО [5; 6-9].

Для вирішення означеної мети були поставлені наступні задачі: встановлення переліку всіх існуючих на сьогодні методик і їх класів; виключення 3 цього переліку методик, що не застосовуються для розробки самих методик - методик методології; визначення переліку основних методик методології; узагальнення отриманих результатів.

Методики дослідження: огляд літературних джерел, 2C70, ВЕО, історично-логічного, індукція-дедукція, теорія методу Бабайлова [6; 8-11].

Виклад основного матеріалу. При вирішенні першої задачі (встановлення переліку всіх існуючих на сьогодні методик і їх класів) були використані результати класифікації методик, проведеної в дослідженні [6]. Це методики фундаментального, експериментального і прикладного досліджень.

До фундаментального дослідження відносять методики: ідею, гіпотезу, концепцію, приватні теорії, основну теорію, науку [6]. До експериментального дослідження відносять методики економічного, технологічного та адміністративного експериментального дослідження. Це методики впровадження нововведень, отриманих у фундаментальному дослідженні. Це і методики розробки нових прикладних методик, технік, технологій або моделей (як синтезу методик і технік). Це методики: експерименту; раціоналізаторства; аналогії (використання відомого досвіду інших сфер діяльності); апробації (контролю, перевірки, узгодження); моделювання (використання моделей як синтезу методик і технік). До прикладного дослідження відносять методики безпосередньої організації виробництва, обміну і самого менеджменту, це методики [6]: мотивації; контролю; ділового спілкування (в основному методики вирішення конфліктів); прийняття рішення; маркетингового дослідження (методики збору маркетингової інформації як методики соціології в маркетингу): вибірка, аналіз документів, опитування, спостереження, експеримент i багато інших; застосовуються i техніки маркетингового дослідження (опитувальні листи, анкети, інтерв'ю, електронні записуючі пристрої); управління якістю персоналу.

Найважливішими методиками прикладного дослідження є й изілі (місія, допоміжні стратегії, загальні цілі та завдання). Будучи результатами економічного експериментального дослідження, надалі вони використовуються в прикладному менеджменті як його засоби, тобто як 
методики. Це і нечисленні методики виробництва (вимірювальні і контрольні процедури) [9].

При вирішенні другої задачі (виключення з цього переліку методик, які не застосовуються для розробки самих методик, методик методології) був проведений аналіз всіх методик фундаментального, експериментального i прикладного досліджень 3 точки зору визначення сфер їх застосування. Він показав, що методики експериментального та прикладного досліджень не застосовуються для розробки самих методик! Вони застосовуються тільки для досягнення основних цілей будь-яких сфер, крім методології. Це сфери економіки, інженерії, адміністрації, підприємництва та інших. Тому методики експериментального та прикладного досліджень були виключені з подальшого розгляду.

Рішення третьої задачі дослідження - визначення переліку методик самої методології звівся фактично до аналізу тільки методик, що залишилися: методик фундаментального дослідження i виділення в ньому методик, придатних для розробки методик тільки методології. Практика сучасних досліджень по розробці парадигм показала, що саме такі методики фундаментального дослідження як ідея, гіпотеза, концепція, приватна теорія, основна теорія, наука і є основними методиками методології. Їх зміст, роль i місце випливає 3 табл. 1.

\section{Модель основних методик (авторська розробка)}

\begin{tabular}{|c|c|c|c|}
\hline \multirow{3}{*}{$\begin{array}{l}\text { Результат } \\
\text { рівнів ФД }\end{array}$} & \multicolumn{3}{|c|}{ Результати етапів фундаментального дослідження (ФД) } \\
\hline & \multirow[t]{2}{*}{ Об’єкт } & \multirow{2}{*}{\begin{tabular}{|l|} 
Предмет \\
(проблемна \\
частина об’єкта) \\
\end{tabular}} & Методика вирішення проблеми \\
\hline & & & Результат вирішення проблеми \\
\hline \multirow[t]{2}{*}{ Ідея } & \multirow[t]{2}{*}{ Методологія } & \multirow{2}{*}{$\begin{array}{l}\text { Невідомість } \\
\text { якісного зв'язку } \\
\text { методології з } \\
\text { методиками }\end{array}$} & Iнтуййія \\
\hline & & & $\begin{array}{l}\text { 3алежність (якісний зв'язок методології з організацією методики } \\
\text { економічного аналізу, наприклад). «Методологія пов'язана } \\
\text { організацією методики економічного аналізу» }\end{array}$ \\
\hline \multirow[t]{2}{*}{ Гіпотеза } & \multirow[t]{2}{*}{ Ідея } & \multirow{2}{*}{$\begin{array}{l}\text { Невідомість } \\
\text { кількісної } \\
\text { залежності } \\
\end{array}$} & Логіка дискретних фактів \\
\hline & & & Закономірність (дискретний якісний і кількісний зв'язок) \\
\hline \multirow[t]{2}{*}{ Концепція } & \multirow[t]{2}{*}{ Гіпотеза } & \multirow{2}{*}{$\begin{array}{l}\text { Невідомість } \\
\text { суцільної } \\
\text { залежності }\end{array}$} & Логіка доказу, розрахунку \\
\hline & & & \begin{tabular}{|llcc} 
Закон & (доведена, \\
«Методологія - це організація методики економічного аналізу»)
\end{tabular} \\
\hline \multirow[t]{2}{*}{ Tеорія } & \multirow[t]{2}{*}{ Концепція } & \multirow{2}{*}{$\begin{array}{l}\text { Непідтверджений } \\
\text { всією практикою } \\
\text { закон }\end{array}$} & Погіка фактів (всієї практики) \\
\hline & & & Закон економіки, підтверджений всією практикою \\
\hline \multirow{2}{*}{$\begin{array}{l}\text { Основна } \\
\text { теорія }\end{array}$} & \multirow{2}{*}{$\begin{array}{l}\text { Теорії } \\
\text { приватні }\end{array}$} & \multirow{2}{*}{\begin{tabular}{|l} 
Відсутність \\
узагальнення \\
окремих законів
\end{tabular}} & Узагальнення окремих законів методології \\
\hline & & & Основний закон «Методологія - це організація будь-яких методик» \\
\hline \multirow[t]{2}{*}{ Наука } & \multirow{2}{*}{$\begin{array}{l}\text { Основна } \\
\text { теорія }\end{array}$} & \multirow{2}{*}{$\begin{array}{l}\text { Основний закон, } \\
\text { методології, } \\
\text { неапробованої } \\
\text { Часом }\end{array}$} & Апробація методології Основного закону Часу \\
\hline & & & $\begin{array}{l}\text { Парадигми методології (глобальна стратегія): в Доіндустріальну } \\
\text { епоху переважали методики фундаментального дослідження; } \\
\text { Індустріальну - методики експериментального та прикладного } \\
\text { дослідження; в Постіндустріальну - методики експериментального } \\
\text { дослідження }\end{array}$ \\
\hline
\end{tabular}


Коротка характеристика ідеї, гіпотези, концепції, приватної теорії, основних теорій, науки була розпочата ще в 2015 році і закінчена в 2019 році [6]. Однак тоді їх ще не трактували як основні методики методології. Так, Ідею трактували як знання, засноване виключно на інтуїції, тільки на припущенні про наявність тільки якісного причинно-наслідкового зв'язку (залежності) проблеми $з$ передбачуваною причиною. Переваги ідеї: це перший і важливий крок від незнання до знання; це основа розробки гіпотези. Недоліки: відсутність твердження; відсутність опори на факти; визначає тільки якісний зв'язок. Для усунення недоліків ідеї формується гіпотеза.

Гіпотеза - це знання більш високого рівня істинності знання. Переваги гіпотези: наявність не тільки припущення, але й ствердження про кількісну залежність (закономірність). Недоліки: наявність припущення; твердження засноване тільки на окремих, дискретних фактах практики, тобто закономірність - це не суцільна кількісна залежність. Для усунення недоліків гіпотези на третьому рівні фундаментального дослідження формуються елементи змісту концепції.

Конщепція - знання ще більш високого рівня істинності. Переваги концепції: наявність тільки ствердження про суцільну i доведену закономірність (закон) у формі графіка або формули - рівності (рідше нерівності). Недоліки: закон в концепції не апробований усіма теоріями i практикою експериментального дослідження! Але практикою виробництва закон не апробується - у виробництві для цього відсутні необхідні умови. За технікою безпеки для цього передбачені спеціальні експериментальні полігони, лабораторії підприємств.

Теорія (приватна) розробляється для усунення недоліків концепції. Переваги теорії: іiі закон апробований усіма теоріями всіх сфер діяльності і експериментальним дослідженням. Істинність теоретичного знання дуже висока. Недолік: відсутність узагальнення окремих законів. Для усунення цього недоліку формується основна теорія.

Основна теорія розробляється для встановлення загального в законах приватних теорій. Ї̈ї переваги: встановлений основний закон як результат застосування методики узагальнення приватних, окремих законів. Недолік: іiї основний закон не апробований часом (епохою) або простором. Для усунення недоліку основної теорії формується наука.

Наука (сутність) - це фундаментальна методика більш високого рівня організації знання, ніж основна теорія. Зміст науки: основна теорія; основний закон; методика апробації часом; парадигма. Переваги науки: містить парадигму, як результат апробації основного закону часом, як глобальну стратегію - стратегію поведінки всього людства в дану епоху в даній сфері діяльності. Парадигма - основа формування місії підприємства. Недолік приватних наук: містять i відносне знання, - прогрес практики, завдяки впровадженню нових законів приватних теорій у менеджмент і виробництво, призводить до відставання i кризи науки (iї парадигми), до необхідності адаптації основного закону до нової епохи, часу (або простору), до необхідності 
зміни застарілої парадигми. При цьому, однак, не старіють інші елементи змісту науки: основна теорія; основний закон; методика апробації часом.

Як видно 3 моделі, методики методології до того ж дозволяють розробити і такі мікрометодики, як об'єкт, предмет, апробація і результат.

Об'єкт встановлює межу дослідження або виробництва; предмет встановлює проблему; апробація - спосіб, правило узгодження; результат - це власне встановлення суті ідеї, гіпотези, концепції, теорії, основної теорії, науки.

Однак методики методології відрізняються за рівнем, глибиною та широтою охоплення знань. Так, об'єкт ідеї - це вся сфера дослідження або виробництва; об'єкт гіпотези - тільки ідея; об'єкт концепції - гіпотеза; об'єкт приватної теорії - концепція; об'єкт основної теорії - приватні теорії; об'єкт науки - основна теорія.

Предмет ідеї - проблема якісного зв'язку об'єкта, тобто, з чим пов'язаний об'єкт. Предмет гіпотези - проблема дискретного кількісного зв'язку об'єкта. Предмет концепції - проблема суцільного кількісного зв'язку об'єкта. Предмет приватної теорії - проблема підтвердження практикою закону зв'язку об'єкта. Предмет основної теорії - проблема відсутності загального у всіх приватних законах об'єкта. Предмет науки - проблема прояву основного закону на різних історичних відрізках часу (епохах).

Методики апробації предмета (вирішення проблеми) в ідеї-це інтуїція. У гіпотезі - це логіка окремих (дискретних) фактів практики. У концепції - це логіка доказу, розрахунку. У приватній теорії - це логіка всіх фактів практики. В основній теорії - це узагальнення окремих законів. У науці - це апробація часом основного закону об'єкта.

Результат ідеї - залежність. Результат гіпотези - закономірність (принцип). Результат концепції - закони (не випробувані практикою). Результат теорії - закон, апробований практикою. Результат основної теорії - основний закон. Результат науки - парадигма (глобальна стратегія, стратегія поведінки всього людства в межах даного об'єкту).

Висновки. Дослідження привело до таких результатів:

- визначено перелік всіх існуючих на сьогодні методик і їх класів - це класи методик фундаментального, експериментального i прикладного досліджень;

- встановлено, що методики експериментального та прикладного досліджень застосовуються у всіх сферах діяльності, крім методології;

- доведено, що до основних методик методології необхідно відносити особливий клас методик, що включає тільки ідею; гіпотезу; концепцію; приватну теорію; основну теорію; науку.

Отримані результати визначають ще один важливий аспект методології iii основні методики. Це буде сприяти підвищенню ефективності застосування методології у всіх сферах діяльності, включаючи і педагогіку вищої освіти. 


\section{Перелік посилань}

1. Hardy M. I know what I like and I like what I know. Epistemology in practice and theory and practice again. 2016. P. 762-778.

2. О методологии педагогики высшей школы: веб-сайт. URL: https://cyberleninka.ru/article/n/o-metodologii-pedagogiki-vysshey-shkoly (дата звернення 12.02.2020)

3. Lystbæk C. Towards Evidence-Reflected Practice: Paradigms as Heuristics in Business веsearch: веб-сайт. URL: http://ezproxy.lib.ucalgary.ca/login?url=https://search-proquestcom.ezproxy.lib.ucalgary.ca/docview/2088045441?accountid=9838 (дата звернення 12.02.2020)

4. Бартенев С. А. Экономические теории и школы (история и современность): курс лекций. М.: БЕК, 1996. 352 с.

5. Социальная экономика: веб-сайт. URL: http://econominfo.ru/viewarticle.php?id=51 (дата звернення 02.02.2020)

6. Бабайлов В. К. Методологія наукових досліджень : навчальний посібник. Х. : ФОП Бровін О.В., 2019. 150 с.

7. Kaushik V., Walsh C. Pragmatism as a research paradigm and its implications for social work research: веб-сайт. URL: https://cutt.ly/NrcOkaE (дата звернення 12.02.2020)

8. Бабайлов В. К. Индукция и дедукция. Бизнес-Информ. 2012. № 10. С. 285-287.

9. Бабайлов В. К. Теория метода: монография. Х. : ХНАДУ, 2011. 232 с.

10. Коуз Рональд: веб-сайт. URL: https://ru.wikipedia.org/wiki/Коуз,_Рональд (дата звернення 12.02.2020)

11. Смит А. О богатстве народов. АСТ Москва, 2010. 188 с.

References

1. Hardy, M. (2016), I know what I like and I like what I know, Epistemology in practice and theory and practice again, P. 762-778.

2. About the methodology of higher education pedagogy [O metodologii pedagogiki vysshej shkoly], available at: https://cyberleninka.ru/article/n/ometodologii-pedagogiki-vysshey-shkoly (last accessed 12.02.2020)

3. Lystbæk, C. Towards Evidence-Reflected Practice: Paradigms as Heuristics in Business Research, available at: http://ezproxy.lib.ucalgary.ca/login?url=https://search-proquestcom.ezproxy.lib.ucalgary.ca/docview/2088045441 ?accountid=9838 (last accessed 12.02.2020)

4. Bartenev, S. A. (1996), Economic theories and schools (history and modernity) [Ekonomicheskie teorii $i$ shkoly (istoriya i sovremennost)] : kurs lekcij. M.: BEK, $352 \mathrm{p}$.

5. Social economics [Socialnaya ekonomika], available at: http://econominfo.ru/view-article.php?id=51 (last accessed 02.02.2020)

6. Babajlov, V. K. (2019), Research methodology [Metodologiya naukovih doslidzhen], FOP Brovin O.V., 150 p. 
7. Kaushik, V., Walsh, C. (2019), Pragmatism as a research paradigm and its implications for social work research, available at: https://cutt.ly/NrcOkaE (last accessed 12.02.2020)

8. Babajlov, V. K. (2012), Induction and deduction [Indukciya i dedukciya], Biznes-Inform, No 10, P. 285-287.

9. Babajlov, V. K. (2011), Method theory [Teoriya metoda] : monografiya, Harkiv: KhNADU, 232 p.

10.Kouz Ronald, available at: https://ru.wikipedia.org/wiki/Коуз,_Рональд (last accessed 10.02.2020)

11.Smith, A. (2010), On the wealth of peoples [O bogatstve narodov], AST Moscow, 188 p.

\section{РЕФЕРАТИ РЕФЕРАТЫ ABSTRAСТS}

\section{УДК 330.8; JEL Classification: B40}

\section{Бабайлов В.К., Левченко Я.С. ОСНОВНІ МЕТОДИКИ МЕТОДОЛОГІї}

Дослідження будь-якої сфери діяльності має свої, властиві тільки йому мету $і$ основні методики його досягнення. Так, мета економіки - організація вартості - реалізується за допомогою методик економічного аналізу та синтезу, економіко-математичних моделей $\mathrm{i}$ інших. Саме основні методики перетворюють цілі в результати. Однак до сих пір не проведена чітка класифікація основних методик за сферами діяльності (економіці, інженерії, адміністрації, маркетингу, підприємництва, філософії, методології та іншим). Невирішеність даної проблеми ускладнює вибір основних методик в реальній дослідницькій практиці. Особливо актуальною стає організація класу основних методик самої методології, так як саме методологія визначає організацію методик всіх інших сфер діяльності. До того ж роль методології буде тільки зростати. Метою даної публікації і стало визначення класу основних методик методології. Для іiі досягнення були поставлені задачі: встановлення переліку всіх існуючих на сьогодні методик і їх класів; виключення з цього переліку методик, які не застосовуються для розробки самих методик (основних методик методології); визначення класу основних методик методології; узагальнення отриманих результатів. Методики дослідження: огляд літературних джерел, 2С70, ВЕО, історично-логічного, індукція-дедукція, теорія методу Бабайлова. Результати: доведено, що до класу основних методик методології необхідно відносити ідею; гіпотезу; концепиію; приватну теорію; основну теорію; науку. Наукова новизна: вперше визначено клас основних методик методології. Практична значимість: визначення класу основних методик методології та їх інтерпретація підвищить ефективність методології та методології педагогіки вищої освіти, зокрема.

Ключові слова: мета; кошти; результати; методики; методологія; клас; сфера діяльності; фундаментальні, експериментальні, прикладні дослідження. 


\section{УДК 330.8; JEL Classification: B40}

\section{Бабайлов В.К., Левченко Я.С. ОСНОВНЫЕ МЕТОДИКИ МЕТОДОЛОГИИ}

Исследование любой сферы деятельности имеет свои, присущие только ему иель и основные методики его достижения. Так, цель экономики организация стоимости - реализуется с помощью методик экономического анализа и синтеза, экономико-математических моделей и других. Именно основные методики превращают цели в результаты. Однако до сих пор не проведена чёткая классификация основных методик по сферам деятельности (экономике, инженерии, администрации, маркетингу, предпринимательству, философии, методологии и другим). Нерешённость данной проблемы усложняет выбор основных методик в реальной исследовательской практике. Особенно актуальной становится организация класса основных методик самой методологии, так как именно методология определяет организацию методик всех остальных сфер деятельности. К тому же роль методологии будет только возрастать. Целью данной публикации и явилось определение класса основных методик методологии. Для её достижения были поставлены задаци: установление перечня всех существующих к настоящему времени методик и их классов; исключение из этого перечня методик, которые не применяются для разработки самих методик (основных методик методологии); определение класса основных методик методологии; обобщение полученных результатов. Методики исследования: обзор литературных источников, 2С70, ВЕО, исторического-логического, индукция-дедукция, теория метода Бабайлова. Pезультаты: доказано, что к классу основнылх методик методологии необходимо относить идею; гипотезу; концепџию; частную теорию; основную теорию; науку. Научная новизна: впервые определен класс основных методик методологии. Практическая значимость: определение класса основных методик методологии и их интерпретация повысит эффективность методологии и методологии педагогики высшего образования, в частности.

Ключевые слова: цель; средства; результаты; методики; методология; класс; сфера деятельности; фундаментальные, экспериментальные, прикладные исследования.

\section{UDC 330.8 ; JEL Classification: B40}

Babailov V., Levchenko Ya. BASIC METHODS OF METHODOLOGY

The study of any field of activity has its own inherent purpose and basic methods of achieving it. So, the purpose of the economy is the organization of value is realized using the methods of economic analysis and synthesis; economic and mathematical models and others. It is the basic techniques that turn purposes into results. However, a clear classification of the main methodologies by fields of activity (economics, engineering, administration, marketing, entrepreneurship, philosophy, methodology and others) has not yet been carried out. The unresolved nature of this problem complicates the choice of basic techniques in real research practice. The organization of the class of basic methods of the methodology itself becomes especially relevant, since it is the methodology that determines the organization of the 
methods of all other areas of activity. Moreover, the role of methodology will only increase. The purpose of this publication was to determine the class of basic methodologies of methodology. To achieve it, the following tasks were set: establishing a list of all currently existing methods and their classes; the exclusion from this list of methods that are not used to develop the methods themselves (the main methods of the methodology); determination of the class of basic methods of methodologies; generalization of the results. Methodology of research: a review of literary sources, 2C70, VEO, historical-logical, induction-deduction, the theory of the Babailov's method. Findings: it is proved that it is necessary to attribute to the class of basic methods of methodology: idea; hypothesis; concept; private theory; basic theory; science. Originality: for the first time, a class of basic methods of methodology was defined. Practical value: the definition of the class of basic methods of methodology and their interpretation will increase the effectiveness of the methodology and pedagogy methodology of higher education, in particular.

Key words: purpose; facilities; results; methods; methodology; class; activity field; fundamental, experimental, applied research.

\section{Відомості про авторів / Сведения об авторах / About the Authors}

Бабайлов Василь Кузьмич - кандидат економічних наук, Харківський національний автомобільно-дорожній університет, доцент кафедри економіки i підприємництва, м. Харків, Україна; e-mail: super_super-kod@ukr.net.

Бабайлов Василий Кузьмич - кандидат экономических наук, Харьковский национальный автомобильно-дорожный университет, доцент кафедры экономики и предпринимательства, г. Харьков, Украина.

Babailov Vasil - PhD in Economics, Kharkiv National Automobile and Highway University, Associate professor of the Department of Economics and Entrepreneurship, Kharkiv, Ukraine.

Левченко Ярослава Сергіївна - доктор філософії 3 галузі «Соціальні та поведінкові науки», Харківський національний автомобільно-дорожній університет, доцент кафедри економіки і підприємництва, м. Харків, Україна; e-mail: slavalevcenko1984@gmail.com; ORCID: http://orcid.org/0000-0002-49791101.

Левченко Ярослава Сергеевна - доктор философии в отрасли «Социальные и поведенческие науки», Харьковский национальный автомобильно-дорожный университет, доцент кафедры экономики и предпринимательства, г. Харьков, Украина.

Levchenko Yaroslava - PhD in "Social and behavioral sciences", Kharkiv National Automobile and Highway University, Associate professor of the Department of Economics and Entrepreneurship, Kharkiv, Ukraine. 